\title{
EU Commission participation in the Troika mission: is there a European Union price to pay?
}

\author{
A participação da Comissão Europeia na missão da Troika: \\ existe um preço a pagar pela União Europeia?
}

http://dx.doi.org/10.1590/0034-7329201500106

ANTONIO GOUCHA SOARES*

Rev. Bras. Polít. Int. 58 (1): 108-126 [2015]

The European Union completed its first political cycle since the Lisbon Treaty came into force. This gave European citizens the opportunity to vote for the European Parliament elections, whereby they had a say regarding the appointment of Mr. Juncker as the new President of the European Commission.

Despite this and other changes introduced by the Treaty of Lisbon, the fact is that the current political cycle of the European Union was less marked by the last Treaty's amendments, as it has been by the political and economic events that shaped the course of the Euro.

Indeed, the Euro crisis has been at the center of European Union politics during the last four years. It was perhaps the most severe crisis during the whole process of European integration (Ash 2012, 11).

A substantial part of the EU's efforts since then have been devoted to so-called "crisis management." European institutions and member states have been working hard to find the appropriate answers to deal with the Euro crisis.

Financial assistance to Eurozone countries with liquidity problems was one of the most visible actions adopted as part of this crisis management. The negotiation and implementation of financial assistance was assigned to a set of institutions, the so-called Troika.

The extent of the Troika's action could raise a number of issues. This article intends to focus on the role of the Commission within the framework of the Troika. The case used for the paper's analysis is based on the Troika's negotiations with Portugal.

\footnotetext{
* Lisbon School of Economics and Management (ISEG), University of Lisbon, Lisbon, Portugal (agsoares@iseg.utl.pt).
} 
The article starts by contextualizing the constitution of the Troika in the aftermath of the sovereign debt crisis and then proceeds with an analysis of the impact of the Commission's participation on the balance of power within the EU's institutions. The second part of the article is devoted to the situation of those countries that were assisted by the Troika, to discuss whether the Commission should have any responsibility for the outcomes of the financial adjustments, taking into account at the same time their readiness for the program's ideological approach.

\section{EU Commission involvement in the Troika}

One of the strongest dimensions of the Euro crisis, initiated during the Greek sovereign debt crisis in early 2010, was the running of financial programs by the so-called Troika, which is a set of institutions that managed the financial assistance provided by international creditors.

It would be useful to remember that the creation of the Troika was due to both a political and a legal gap in the Treaty of Maastricht, ${ }^{1}$ which prevented Eurozone countries with liquidity problems from being supported by other stakeholders within the monetary union, such as the European Central Bank (ECB), European Union institutions or other Euro-area countries.

The initial move to set up the Troika was provided by the decision by the heads of government of the Euro area to concede bilateral loans to Greece, in March 2010, in a package that also involved significant IMF financing. According to Eurozone lenders, financial assistance to Greece would be subject to demanding conditions and would be based on an assessment carried out by the European Commission, in liaison with the ECB, working together with the IMF.

Therefore, the Troika represents a working-group composed of the European Commission, the European Central Bank and the International Monetary Fund, which is in charge of negotiating financial assistance programs with Eurozone countries that have liquidity problems. It also has the role of carrying out periodical assessments of the level of the implementation of the program.

Financial assistance in itself, however, was provided by special vehicles created by Eurozone countries over time (EFSM; EEFS; ESM) ${ }^{2}$ and also by the International Monetary Fund. Lending conditions were to be defined by these financial providers.

It should be noted that financial assistance programs agreed with Eurozone countries were enabled outside EU Treaties and the formal European Union framework. Irrespective of concerns regarding the competence of the EU to manage

1 The combined effect of the so-called "no bailout clause" (art. 125 TFEU), with a provision that forbids the ECB to act as a lender of last resort (art. 123 TFEU).

2 The European Financial Stability Facility (EFSF) and the European Financial Stabilization Mechanism (EFSM) are temporary vehicles created in 2010. The Treaty on the European Stability Mechanism (ESM) was signed in February 2012. 
the sovereign debt problems of some of the Eurozone countries, the main point is that those programs were beyond the jurisdiction of European Union law.

Then, the question as to be raised is the role assigned to European Union institutions within the framework of the financial assistance programs, and, in particular, that of the European Commission.

It is well known that the European Union, and its institutions, should act under the basis of the rule of law. That is to say, that any action to be carried out by the Union, or through its institutions, should conform to the principles established by the Treaties.

However, the European Commission did not participate in the negotiations for financial assistance programs, neither in the ongoing assessment of the implementation of those programs, with the legal status of a European Union institution.

Instead, the European Commission participated in the so-called Troika negotiations, and the periodical supervising exercises, on behalf of the member states that provided the loans to the Eurozone countries in financial need. Therefore, in this case, the European Commission did not act as an independent institution, as it typically does within the framework of the European Union (Pisani-Ferry 2013, 21-24).

As has been mentioned, the financial assistance programs were drawn up beyond the scope of the European Treaties, despite the fact that they were passed in order to solve a problem that was affecting the core of European integration-the stability, and even continuity, of the single currency.

In spite of the nature of financial assistance programs, there are, in fact, some issues that can be raised that strongly impact on the functioning of the European Union. For a start, the involvement of European institutions, especially the European Commission, raises some concerns regarding the institutional balance of the European Union political system.

It is well-known that one of the strengths of the process of European integration lies with the institutional system of the European Union. The institutional framework of the Union was drafted on the basis of Jean Monnet's vision, which defended that a unified Europe should be based on strong and independent institutions. Those institutions should be able to counter the traditional balance of powers between the most influential European nations, which has caused huge damage in the past.

From the beginning, the construction of Europe was made on the basis of its institutional framework, an example being that the Coal and Steel Community (ECSC) was supervised by a fully independent Higher Authority, chaired by Jean Monnet himself.

With the advent of the 1957 Treaties of Rome, the European Commission took over the position of the ECSC Higher Authority. Ever since then, the European Commission has been an independent institution, whose members are 
not allowed to take instructions from any Member State, and it must only defend the general interest of the Union.

These reasons also explain the fact that the European Commission was always seen as a traditional ally of small and medium member states in their dealings with the larger EU countries (Peterson 2006, 92), which otherwise would have had a stronger say in European affairs. In a similar manner, the European Commission tended to take special care of weaker nations, in order to promote a harmonious development of economic activities throughout the Community, a European mission expressly assigned in the Treaty of Rome.

Taken into account the role conferred by the Treaties to the European Commission, and its long commitment as an independent institution since the beginning, it has served as a parachute for small and medium member states, protecting them against the ambitions of some of the more powerful nations. Thus it should be asked whether the working of the Commission within the framework of financial assistance programs for Eurozone countries could, in some way, undermine its political position within the EU political system.

Needless to say, the fact that the European Commission is acting on behalf of the member states in the case of financial assistance programs, is clearly separated from its political role within the EU political process. Indeed, by accepting this task that was conferred by the member states, the Commission is refraining from acting as an independent institution.

Moreover, the Commission appears in a subordinate position with regards to those who gave it the mandate to act within the framework of financial assistance. In fact, the Commission is acting as an agent of the member states, in a role that does not conform to its legal status within the EU political system.

Therefore, it could be said that the way that financial assistance programs for Eurozone countries were designed, in institutional terms, weakened the European Commission's political role within the EU political process.

It should be stressed that the assessment of the general interest of the Union in the framework of the Euro crisis could be debatable. Indeed, this crisis not only caused a new cleavage among Eurozone countries-between creditors and borrowers - but it should also be taken into account that the Euro is a currency used by less than two thirds of EU member states. Moreover, it was clear from the beginning that creditor and borrower countries were providing conflicting narratives on both diagnosis and therapy for the crisis.

The fact that the Commission appeared in the Troika negotiations as a nonindependent institution, acting on behalf of the member states, could also raise the question as to whether the Commission is playing a role that is in some way more similar to that of a Secretariat of an international organization.

Indeed, most of the decisions concerning the functioning of the monetary union that were taken in the aftermath of the Euro crisis, were decided at an intergovernmental level, especially those regarding the creation and functioning 
of the European Stability Mechanism, which supervises the provision of financial assistance to Eurozone countries. Despite the use of a non-community method for some of the new Euro-area tools, the Commission is deeply involved in its implementation-as occurred in the case of the Troika negotiations.

Hence, Troika negotiations - which were a central feature of the European Union's reaction to the Euro crisis_could affect the rank of the Commission within the framework of the European political process.

The fact that the Commission was not acting as an independent institution, that it could not address the general interest of the Union in a wider perspective and neither was it able to protect the interests of weaker member states against the will of the more powerful ones, all contribute to a case for relegating the political status of the Commission.

\section{A continuous trend}

Those events could even have been accepted by some, if they had been considered to be exceptional in the face of an emergency situation, such as the turmoil that affected the monetary union in the aftermath of the international financial crash. At that time, international markets took advantage of the weaknesses of the single currency system up to a point whereby the whole project of an European currency was at stake for a while, and Eurozone countries were forced to react to sustain the Euro in such a way that did not take into account the composite checks and balances that are fundamentals of the European Union political process.

However, the issues underlined above refer to two dimensions of the political status of the Commission - the downgrade of the Commission's political role, and its lack of independence regarding member states, both of which are problems that have been recognized for more than a decade.

Indeed, the centrality of the Commission's role in the EU political process has been undermined by the set of constitutional amendments adopted since the Maastricht Treaty, in 1992. In particular, with the growing role of the European Parliament in EU politics-it has been a constant in all the amending treaties ever since then, ranging from Amsterdam to Lisbon-which was achieved at the Commission's expense, a problem that came to the surface with the resignation of the Santer Commission in 1999.

Moreover, after reaching its peak of political performance during the Delors' governance, it would be harder for subsequent Commission's presidents to maintain the significance of this institution within a more politicized Union that was endowed with a double legitimacy, being that of both its member states and its citizens. Hence, the growing role that has been conferred to the European Council and to the European Parliament has reduced the Commission's political visibility, and this effect has been compounded by its own successive weak leaderships. 
Besides, the independence of the Commission from member states is now being put into question more often. Indeed, the composition of the Commission by a representative from each EU country tends to weaken the very supranational nature of the institution. This trend became more evident after the Eastern enlargement, whereby new countries looked to its Commissioner as their representative.

As noted by Piris, a Commission composed of 28 members, where most of Commissioners tend to defend their own country's concerns, risks falling into intergovernmentalism (Piris 2012, 26), which is precisely the contrary of the Commission's initial purpose: to be a supranational institution, that stands above individual member states' interests.

Hence, the role played by the Commission in the framework of the so-called Troika is a further step in the new balance of power within the European Union's political process, which has seen the Commission losing ground and political influence over the last years (Webber 2013, 14), vis-à-vis the other institutions, especially with regard to the European Council and the European Parliament.

However, the novelty that these Eurozone financial assistance programs brought to the EU political process, was of the European Commission acting in clear hierarchical dependence of the will of the member states, in particular, those that had a stronger voice in shaping the EU's reaction to the Euro crisis.

\section{Lost sovereignty}

The financial assistance provided to Eurozone countries was not given as a single payment, but rather loans were made across a certain span of time-which was calculated to be that necessary for the assisted countries to regain full access to the financial markets - that was normally fixed at three years. During that period of time, the Troika authorized the payment of the various tranches of the total financial package every quarter, after careful assessment of the progress of the agreed terms of implementation that had been established in the initial loan contract - the so-called Memorandum of Understanding.

These quarterly meetings with national authorities were aimed at supervising the level of national compliance with the established goals and financial conditions of the program, in order to liberate the next monetary tranche of the program. Hence, Troika negotiators were endowed with strong powers to oblige the implementation of the conditions set out in the initial agreements, insofar as they could recommend the suspension of the financial loans at any moment, resulting in a consequent freezing of various public commitments in the country in question.

Indeed, the Troika's ability to use that power in the assessment of financial assistance programs became one of the most striking aspects of the whole of financial assistance in the Euro area. In particular, the European Commission proved to take an even more inflexible approach than the renowned IMF financial adjustment 
hardliners within the framework of the working-group in charge of supervising financial assistance to Eurozone countries.

The Troika's quarterly assessments were so strict, that in practice, national governments had no other choice but to regularly follow the solutions recommended by Troika officials, despite the fact that countries were supposedly meant to maintain the power to make their own decisions as how to implement the financial assistance program's goals.

In fact, as the periodical assessments progressed, Troika officials progressively played a much stronger role, due to the fact that they could decide whether the affected county was on track to receive the remaining tranches of financial support, or not.

If one takes into account the way that the Portuguese government dealt with this situation, the nature of Troika activity would perhaps become clearer. From the beginning, the Portuguese deputy prime-minister, Paulo Portas, referred regularly that his country had turned into a de facto Protectorate, due to the financial assistance constraints.

The toughness of the Troika officials was reflected in the language that leading Portuguese government members used to refer to the situation that the country was facing during the period of financial assistance. Obviously the legal concept of a Protectorate was not compatible with the approach taken by the Troika negotiators, but the point is that they basically got to impose most of their preferences on the Portuguese government. In this sense, the Portuguese Prime Minister Coelho remarked that the country was facing a situation whereby it had lost sovereignty, in the sense that national authorities lacked the ability to decide by themselves most of the decisions that had fiscal implications.

This view was also subscribed to by other main European heads of government, such as Italy's former Prime Minister Monti—and previous European Commissioner - when he resisted asking for financial assistance at the peak of the Euro crisis, arguing then that Italy was not to be treated as a colony. ${ }^{3}$ Thus a renowned political actor of the last decade of European integration used an even stronger term to define the kind of relationship that was developing between national governments and Troika officials.

Likewise, former Prime Minister Zapatero fought against the insistence of the ECB and some Eurozone countries that Spain should receive financial assistance ${ }^{4}$, which can be seen as another political rejection of being forced to accept such an embarrassing status for a country.

3 "Eravamo sul punto di diventare una colonia [...] Paesi che hanno dovuto cedere pezzi della propria sovranità nazionale [...]" See: Monti, M. (2012): "L'Italia non è una colonia". Available at: http://www. corriere.it/politica/12_maggio_12/monti-italia-non-e-colonia-ue_3c722d76-9bf2-11e1-a2f4-f4353ea0ae1a. shtml\#ryy41hFLTMHbKEjK. Accessed: 25/11/2014.

4 “...Merkel me planteó si estaba dispuesto a pedir una línea de ayuda preventiva de 50.000 millones de euros al FMI.”, (Zapatero 2013, 270). 
Thus, it seems that the European Commission took it seriously the mandate received from Euro countries' lenders and adopted a stance towards Eurozone member states with liquidity problems that seemed to forget some of the inspiring guidelines that were enshrined in the original establishment of the European Union political process, namely, the equality of all member states and solidarity among European nations to balance the hegemony of the most powerful countries.

\section{Output of the Troika}

Troika officials have a strong involvement in the making of financial decisions by assisted countries. Indeed, those countries are expected to make formal decisions that incorporate Troika guidelines into their laws and, moreover, are obliged to implement those measures. Hence, affected countries were strongly influenced by representatives of the Troika, whose opinions were based on the conditions set down in the original Memorandums of Understanding, as well as their own technical knowledge.

Therefore, and despite the fact that the concrete measures taken in each Eurozone country within the framework of financial assistance programs were only adopted by national authorities, there is another issue that should be raised: can any political responsibility be assigned to the international institutions that were involved in the negotiations with the Troika?

Indeed, some influential leaders of the Troika institutions, such as Olli Rehn, former Commission's Vice-President, remarked more than once, that financial decisions made by assisted Euro area countries can only to be credited to those member states. That is to say that the Commission discarded any responsibility for decisions taken during the financial assistance process.

However, if one takes into account the strict supervision undertaken by the Troika every three months — which could have led to a suspension of the flow of funds whenever the Troika considered that national governments were not taking the appropriate measures to comply with the conditions established in their financial assistance agreements - it can be seen why leaders of both countries that accepted financial assistance and those that struggled to avoid receiving financial assistance, found it hard to accept such a formalist reasoning for the liability of the Troika institutions.

Even if all the proposed economic policies and fiscal measures had been formally adopted by assisted countries at a national level, in accordance with their constitutional rules, the fact remains that national authorities went through severe scrutiny by Troika officials before a significant number of those decisions were made.

Therefore, it cannot be said that the institutions of the Troika did not take part in the choice of national decisions that were taken in the course of financial 
assistance programs and that they solely resulted from national choices that were only conceived and adopted by domestic institutions.

Thus, and despite the fact that the areas of economic and fiscal policy formally belong to the exclusive jurisdiction of member states, assisted countries were clearly in a dependent situation throughout the time of financial assistance, in the sense that they were unable to officiate major economic and fiscal decisions without prior approval of Troika officials.

For these reasons, attempts to assign exclusive legal and political responsibility to national governments for the entirety of measures taken within the framework of financial assistance programs, can be seen as an effort to release Troika entities of any liability.

Based on the fact that the IMF is an organization that can hardly be accountable in political and legal terms for financial assistance actions taken around the world, on account of the nature of international law, European Union institutions could face a more stringent control of their actions, by means of legal and political tools that are available under European law.

Beyond using European law procedures to scrutinize the action of European institutions that took part in Troika negotiations, in particular the Commission, it is unlikely that those institutions will totally reject any sort of political liability for the economic and fiscal policies that were taken by assisted countries over the course of financial assistance programs. The severe scrutiny of national measures that was made by the Troika at least raised the issue of the intellectual, or moral, responsibility for the content of those measures. Indeed, it would be hard to deny that the Troika representatives technically inspired some of the measures adopted by national authorities, not to mention cases were they had been the true authors of decisions passed by the governments of assisted countries.

It is worth to remember that the Commission represents the bureaucratic arm of the European Union. Since the beginning of European integration, the Commission has been the institution most endowed with technical knowledge that enabled the European Community to achieve the goals fixed by the Treaty of Rome.

In fact, Jean Monet's vision of the role of the European Commission was based on the need to create an institution with a high level of technical knowledge on issues related to economic integration. Its success was to rely on the work of technical experts, who were independent from the member states. As a result, the Commission was to be acceptable to the political and economic elite involved in European construction. Thus, in the earlier phases of European integration, the legitimacy of the Commission resulted mostly from the technical expertise of its bureaucrats (Cini 2002, 6).

Needless to say, this perspective has been sidelined by the developments of the whole process of European integration, and by, in particular, the creation of the European Union, which led to deeper concerns as to the democratic nature 
of European institutions and the whole European political process. As a result, the legitimacy of the Commission came to be viewed more on a political basis, rather than from a technocratic perspective. Given the issue of the democratic legitimacy of this institution mostly lies with the work carried out by the College of Commissioners, the administrative body of the Commission needs to market its technical knowledge, in order to be accepted by other EU political actors.

The Commission's participation in the Troika was justified on grounds of its technical expertise regarding issues related to economic and monetary union. Indeed, the Commission representatives approached on the course of Troika negotiations referred that the Commission was in a unique position to deal with the main economic and fiscal problems that affect Eurozone countries when they ask for financial assistance. Hence, the role of the European Commission in Euro crisis management is also due to its technocratic standing.

In fact, Commission departments in the area of financial and economic affairs have been analyzing the economy of member states for a long time, and in particular, the Eurozone countries. Hence, the Commission was supposed to be in a privileged position to better understand the factors that have affected countries situated at the periphery of the Euro area since 2010, especially when compared with other international institutions, such as the IMF, which is the leading organization for financial assistance world-wide.

\section{Financial adjustment outcomes}

Portugal asked for financial support one year later than Greece, and six months after Ireland, in April 2011.5 It was then expected that the Commission would recommended a set of economic policies and fiscal measures that would allow the country to overcome its liquidity problems by restoring sound public finances data, to put the economy back on track and regain full access to international financial markets.

The huge task ahead of Portuguese authorities in mid-2011 was to be supervised by the technical knowledge of the Commission, in liaison with the European Central Bank, working together with the International Monetary Fund. It is well-known that financial adjustment headed by international organizations is most likely to be achieved through budget stability—based on tax rises and spending cuts—and structural reforms.

5 In the framework of the financial assistance program, Portugal received external loans over three years for a total of $€ 78$ billion. The loans were provided by the European rescue funds ( $€ 26$ billion by the EFSF and $€ 26$ billion by the EFSM), with the additional $€ 26$ billion coming from the International Monetary Fund. The last financial transfer of $€ 0.4$ billion was received from the EFSM in November 2014, bringing the total bail-out to $€ 76.8$ billion, out of $€ 78$ billion (the government declined to receive the last tranche). Portugal will have to pay back the IMF loan in 7 years, with an interest rate of $3.5 \%$. The EFSF loan must be fully refunded in 20 years, with a $2 \%$ interest rate; the EFSM loan has to be repaid in 19 years, with a $2.9 \%$ interest rate. 
Hence, the main issues at stake were how to balance the increase on taxation with the extent of cuts to government and public sector spending, and how to spread the intensity of those measures over the timeline of the financial assistance program.

Under close supervision by Troika representatives, the Portuguese government went on to undertake a period of frantic activity that approved measures, in respect of spending cuts, that seriously reduced civil servants' salaries, cut pensions payments, made deep cuts to the funding of the National Health Service, closed public schools, hospitals, law courts, tax departments and other public services across the country, whilst considerably decreasing Social Security benefits for the poor and the unemployed.

These spending cut measures were taken at the same time that the national parliament approved all the Government's proposals which led to an increase in taxation. At the beginning of the program, sales tax (VAT) suffered a general rise for the majority of goods and services, and in 2013, personal income and real estate taxation were also subject to huge increases, to refer the words of the then finance minister. Tax increases were complemented by a rise on employees' Social Security levies and on fees paid for the use of the Public Health Service.

Furthermore, Troika representatives pressed for a large privatization campaign that saw airports, electricity production and distribution, the Post Office, insurance companies and many other State assets be sold over a short period of time, together with a program for privatizing public transport services and other public utilities.

There was also a vigorous agenda for making structural reforms that saw severe modifications of the labor law and industrial relations as a means of reducing production costs and increasing labor flexibility. Local public government was subject to mergers, the judicial system was reformed, a new public procurement system was implemented, competition law was amended, and public administration was reformed.

As a result of these profound transformations, the country was turned upside down with regards to the way public services were run, the functioning of public administration and, in general terms, the handling of the economy. The Troika's shock therapy achieved some fast results, in particular, regarding the current account balance, and Portugal passing from having a deficit of almost 10\% of GDP in 2010, to a surplus in 2013, an outcome that hadn't occurred since the Second World War.

Together with reducing private debt, there was also a drop in the public deficit, although this took place at a slower pace than that which had been set by the financial assistance program. ${ }^{6}$ Indeed, the country was unable to meet the target

6 Portuguese budget deficit passed from 3 percent in 2007 and 3.8 percent in 2008 to an enormous amount of 9.8 percent in 2009 and 11.2 percent in 2010. On the basis of such a slippage of government deficit was the brief embrace of Keynesian economics by almost all Western governments to counter the negative effects of the international financial crash caused by the collapse of the Lehman Brothers (Blyth 2013, 54). Moreover, Portugal faced legislative elections in late 2009, which furthered the increase of public spending. For data on budget deficit, see: http://ec.europa.eu/eurostat/tgm/table.do?tab=table\&plugin=1\&language=en\&pcode=tei na200. Accessed: 04/02/2015. 
for the fiscal deficit of $3 \%$ of the GDP by 2013, despite a multiplicity of spending cuts and significant increases on taxation. Still, in 2013, the overall government deficit almost reached 5\% of Portuguese GDP (EP 2014, 42).

One of the main reasons that could explain the slippage of public deficit goals was the global effect of financial assistance fiscal policy measures on economic growth. Indeed, economic slowdown caused by severe austerity measures was deeper than that anticipated by Troika forecasts, with a GDP contraction of $3.2 \%$ in 2012 and $1.8 \%$ in 2013. Accumulated GDP loss in the period 2011-2014, which corresponds to the duration of the financial assistance program, is expected to reach 5.5 percentage points (EP 2014, 40).

This deep economic contraction also explains the social damage that has been caused by financial assistance. The unemployment rate has almost doubled, when compared with 2009, reaching more than 17\% in 2013 (EP 2014, 39). Moreover, emigration rose strongly over 2012 and 2013, with an estimated 100,000 people having left the country each year in search of work. Therefore, official unemployment rates do not fully reflect the extent of the destruction of jobs by economic contraction, as it does not reflect the quantity of economic emigrants.

Along with the level of unemployment, public debt was the other main failure of the financial assistance program. According to Eurostat, public debt represented $94 \%$ of GDP at the end of 2010. During the adjustment time of the program, overall government debt suffered a sharp rise of 35 percentage points, to overcome $130 \%$ of GDP at the end of financial assistance in $2014 .^{7}$ As referred to below, when the sovereign debt crisis first erupted, European institutions such as the EU Commission, the European Council and the ECB, all accepted that the borderline for debt sustainability was to be fixed at below $90 \%$ of GDP.

The increased amount of Portuguese public debt will be, much probably, one of the major legacies that the financial assistance program left the country. It remains to be seen whether Portugal will be able to deal with any upsurge in nominal interest rates in international markets after the end of financial assistance.

\section{The political responsibility of the Commission}

The increase of Portuguese government debt by 35 percentage points during the Troika-managed financial assistance program is an irrefutable fact. From a level of $94 \%$ of GDP in late 2010 , government debt surmounted $130 \%$ of GDP at the end of the program in 2014. When the Troika officials first arrived, the Portuguese debt as a percentage of the GDP was even comparable with the level of German debt, which was $82.5 \%$ of GDP at the time. By the end of the financial assistance program, Portuguese debt had reached an extent similar

7 See: http://ec.europa.eu/eurostat/documents/2995521/6483082/2-22012015-AP-EN.pdf/765eba70-6a884771-8af7-48f6665e3c67. Accessed: 05/02/2015. 
to that of Italian debt, which was $131 \%$ of GDP in 2014 (Commission 2013, $17,29,43) .8$

As was referred to above, the Troika authorities had a strong bargaining power during the period of financial assistance, due to the fact that it is they that decided whether to release, or not, the next financial tranche of the bailout package to the assisted country. The exercise of this power during trimestral assessments seriously constrains the implementation of discretionary measures by national governments in the areas covered by the Memorandum of Understanding.

Moreover, it has been stated that bailed-out countries live on a sort of limited sovereignty during the whole period of finance assistance. The way heads of government of various southern European member states referred to that situation seems to be unambiguous as far as the political need of national authorities from Troika institutions depends, regarding the whole area of economic and fiscal policy.

Leaving apart the responsibility of the IMF, it is of interest to raise the question as to what extent the EU institutions should be accountable for the results achieved during the period of financial assistance, especially for the increase in public debt.

It is worth recalling that the uniqueness of the European Union supposedly relies on the fact that during the whole process of European integration, its institutions, in particular the European Commission, are supposed to act in the general interest of the Union, countering the influence of the most powerful members.

Thus, whereas EU institutions can take the honors for the greatest European achievements across time, they should also be blamed for the decisions that proved to be wrong. According to a well-known European Court of Justice decision the EEC was a Communauté de droit, ${ }^{9}$ i.e., an entity that had to be governed under the strict rule of law observance.

The fact that financial assistance programs were adopted outside the scope of EU Treaties, as was mentioned above, has turned the legal responsibility of EU institutions involved in the process into a complex issue. Indeed, the European Commission was not acting in fulfillment of the functions assigned in the Treaties, neither by any legal acts passed during the implementation of those Treaties. The Commission acted with a different status — on behalf of those member states who were bailout lenders.

However, it could be said that there should be no legal responsibility regarding the Commission's action during the conception of the framework of the Troika's mission, as it be would be difficult to provide clear evidence of the

8 According to Eurostat, Portuguese government debt was 131.4\% of GDP in 2014 (Q3), while Italian government debt was $131.8 \%$ in the same period. Available at: http://ec.europa.eu/eurostat/documents/2995521/6483082/222012015-AP-EN.pdf/765eba70-6a88-4771-8af7-48f6665e3c67. Accessed: 05/02/2015.

9 Case 294/83, Parti écologiste “Les Verts” v. European Parliament, ECR 1986, p. 1339. 
Commission's authorship of the most controversial measures that were decided during the design of the framework of financial assistance and, also, to establish an irrefutable link between such eventual proposals and the failures that occurred in bailed-out countries.

That does not mean that the Commission's action regarding the work of the Troika should remain fully exempt from any sort of legal review. In a Communautée de droit, no political body should enjoy absolute legal immunity.

Nevertheless, the Commission's responsibility should be mainly discussed in political terms. In fact, within the Eurozone, there seems to be a wide consensus for the existence of a ceiling for debt sustainability. That consensus is based on a famous article by Reinhart and Rogoff, which traces government debt sustainability to a limit of total public debt corresponding to $90 \%$ of GDP (Reinhart and Rogoff 2010, 578).

Despite the academic debate as to the accuracy of this ceiling, the fact is that this upper limit is a political reference for mainstream Eurozone economic policy. According to Olli Rehn's address, countries that exceed a public debt limit of $90 \%$ of GDP, seriously risk facing an unsustainable debt situation, due to its major negative impact on economic growth, which would deeply affect their credibility vis-à-vis the international financial markets (Rehn 2010, 3). ${ }^{10}$

In the case of Portugal, the zenith of the financial assistance program was the area of fiscal policy, which was aimed at reducing public debt and the deficit (Pisani-Ferry et al. 2013, 91). However, and despite the zeal displayed by national authorities in carrying out the Troika's recommendations, the country is faced with a huge increase in its public debt—about 35 percentage points—over a period of just three years.

Hence, it is rather clear that the Commission influenced the way fiscal policy was to be conducted during the financial assistance period. If at the end of the assistance program the country is faced with a level of public debt that significantly overcomes the ceiling of debt sustainability, then it seems reasonable to ask whether the Commission should be considered for any sort of liability for the results achieved in this area. As in any partnership, profits are to be shared by all, and losses should be divided by the parts.

At the end of the program, the Commission, acting on behalf of European creditors, should be recognized for the successes of the program, namely, the balance of trade result and the decrease in public deficit. Under the same reasoning, it should assume the responsibility share for the collateral damages that have been caused by financial adjustment, and, in particular, the increase of public debt and the social impacts, such as the high unemployment rate.

In the case of assisted countries, creditors entrusted the Commission, along with other Troika institutions, with the task of conducting financial adjustment

10 Rehn, O. (2010), Available at http://ec.europa.eu/commission_2010-2014/rehn/documents/cab20130213_ en.pdf?_ga=1.145968756.1985743091.1394036687. Accessed: 17/09/2014. 
programs. If, at the end of these programs, and despite faithful implementation by national authorities, some parts of these programs went wrong, it seems fair that the managing institutions should assume their share of the responsibility. It needs to be made clear that this situation should not be confused with the question of debt mutualization.

Indeed, EU institutions involved in the Troika, together with member states creditors, have implicitly admitted their faults by already agreeing to reschedule EU loans to Greece, Ireland and Portugal. However, the extent of the growth of debt caused as a result of financial assistance programs should be treated as a core European political issue, and creditors should assume their share of failures. Bailed-out countries who diligently implemented the Troika's shock therapy should see a part of the Troika-added portion of its public debt readjusted in the framework of a European initiative designed to address this issue.

\section{Ideological routes}

The European Commission is a core political institution in the EU political process. Positions taken by the Commission are supposed to reflect its political analysis of the facts whilst implicitly reflecting its ideological assumptions.

Since the emergence of sovereign debt crisis in 2010, at least, two opposed narratives have sought to explain the situation that has affected some Eurozone countries. Initially, the European Union's most powerful countries stressed the fact that Greece did not comply with Stability Pact rules for long and, as a consequence, financial markets feared its ability to comply with debt repayments. As a consequence, any financial support to Greece would have to be based on strict rules of conditionality, especially in the area of fiscal policy. This view has been shared by the Commission since the beginning of the Euro crisis.

With the onset of the contagion of sovereign debt to other countries, it became clearer, however, that the Euro crisis was not only due to the existence of profligate member states in the Euro area periphery. Instead, the Eurozone had suffered from some fundamental macroeconomic imbalances which were intensified over time, namely, the accumulation of large current accounts deficits by southern European countries, together with the existence of a vast trade surplus in Germany and in some other countries (Feldstein 2012, 110). In the words of Moravcsik, bankruptcy in southern Europe and prosperity in Germany were two sides of the same coin (Moravcsik 2012, 57).

Despite the fact that the Commission took a long time to warn of the existence of important macroeconomic imbalances within the Eurozone, it never attempted to suggest a more comprehensive approach to explain the various reasons that led to the Euro crisis.

On the other hand, it is well known that in the aftermath of the 2008 financial crash, most Western countries adopted a pro-Keynesian economic policy, in order 
to avoid an economic contraction similar to that which occurred during the Great Depression. As a result, there was a general increase in public spending-partly aimed at injecting money into financial institutions, to prevent major systemic bank failures from taking place - along with the adoption of an expansionist monetary policy (Krugman 2012, 188).

However, in 2010 the ECOFIN Council initiated a major turn in economic policy, paving the way for the so-called "doctrine of expansionary fiscal adjustment" in Europe, which took an even stronger stance and intensity in bailed-out countries. This new phase was inspired by a well-known Alesina paper which defended the expansionary effect of public spending cuts. Taking into account the increase of deficits and debts in most Western nations on account of financial bail-outs, this paper claimed that the solution for fiscal policy should consist in making severe cuts to government spending.

The grounds for the spending cuts approach was the rational expectations theory, which basically defends that consumers will quickly incorporate such cuts by the Government in their own spending decisions, taking advantage of the lower interest rates that will follow this new fiscal policy approach. Hence, according to this view, rational expectations of consumers would turn government spending cuts into an expansionary economic policy (Blyth 2013, 173-76).

The interesting aspect about the suddenly inversion in European Union economic policy, was the lack of a rigorous basis for such a move. As was pointed out by Krugman, in normal circumstances, academic research plays a minor role in the political debate that results in the making of economic decisions, as decisionsmakers lack the technical skills needed to assess the soundness of such studies. Instead, the measures proposed in Alesina paper were immediately embraced by the European Union political elite (Krugman 2012, 197).

This fast decision on economic policy by the ECOFIN Council could even be understood to a certain degree. The Economic and Financial Affairs Council gathers treasury ministers from EU member states. Most of the EU countries were governed by conservative parties at the time. One could accept that those governments would like to move away from the pro-Keynesian economic policy that had been adopted in the aftermath of the Lehman Brothers' case. Therefore, the decision taken in its 2010 April session was mainly driven by ideological grounds. Besides, and as it was noted by Piketty, by electing austerity as the zenith of Eurozone fiscal policy Europe took the worst solution to reduce government debt (Piketty 2013, 885-90).

However, the European Commission is an institution which, apart from representing the general interest of the Union, claims to possess profound technical knowledge, especially in the areas of the economy and of the economic policy of the member states. It is rather peculiar, in fact, that the Commission did not even question the appropriateness of Alesina's thesis in being fully applied to the weaker economies of the Eurozone, with an even increased intensity. Hence, it 
also seems that the Commission let ideological preferences take the lead over its economic expertise.

Those ideological traits of the Commission could be identified in most of the measures recommended by the Troika on the expenditure side, such as double-digit public sector wage cuts and reductions of pension and other social benefits, spending cuts across numerous welfare state services, from public heath to education through to Social Security, public housing and public transportation. Such policies were normally followed by the privatization of public utilities, namely those that would bring equal opportunities that could not be provided by market failures (Streek 2013, 174).

The fact that the Commission easily converted to the route of a new economic policy — with a clear ideological background — which was mostly determined by stronger member states, who also provided a part of the financial assistance to Eurozone countries, and that the Commission took a hard approach with regards to the implementation of Troika measures, made this institution look as if it favored powerful countries, whilst it was tougher with the more fragile member states.

\section{Conclusion}

Financial assistance programs paved the way for deep institutional challenges within the European Union. The fact that member states that had provided financial support to countries with liquidity problems decided to outsource the task of negotiating the conditions attached to the bail-out programs to the Commission, together with the supervision of their implementation, enabled this institution to act in areas that go beyond the jurisdiction of the EU and that transcend the boundaries of its own powers.

However, the Commission undertook that task on behalf of the member states, that is to say, the Commission did not act in its usual status of an independent institution. The Commission had become more dependent on the will of some of the member states, who had provided the bulk of financial assistance. Hence, the Commission was not seeking to find the best solution for the general interest of the Union.

The relegation of the Commission to a non-autonomous role would have been an area for concern alone, bearing in mind the tendency in the context of the EU political process for a continually growing influence of the European Council and of the European Parliament in the balance of power of the EU institutions. However, the fact that decisions regarding financial assistance were taken out of the scope of action of the European Parliament makes the case of the Commission's role in the policy decisions of the Troika an even more worrisome subject, insofar as it left weaker countries almost at the mercy of the more powerful member states. Therefore, when the Euro crisis deepened member states that required a bail-out could hardly benefit from the protection of the Commission. 
Beyond the rearrangements of the balance of power caused by the Euro crisis, another issue comes to light regarding the Commission's participation in the Troika: its political liability. The experience of being involved in the process of financial assistance allowed the Commission to exercise a degree of political influence over a group of member states at a level that had never been seen before in European integration. Indeed, the Commission was able to determine a wide range of economic and fiscal policies decisions that were taken by member states receiving assistance, whilst at the same time it was able to employ stronger methods of policy enforcement.

As in any democratic polity, greater power involves more responsibility. If the Commission had had a sound influence over economic and fiscal policy measures that were taken by a bailed-out country during its assistance program, and if it had exercised a stricter control over its implementation, then it should also take responsibility for a share of the final outcome.

One of the long-lasting legacies of the activity of the Troika will certainly be the upsurge in public debt of those countries that were subject to its assistance program. In the case of Portugal, in just three years, it passed from having a public debt in terms of GDP percentage similar to that of Germany, to having one with a level close to Italian debt in GDP terms. This trajectory was made under strict EU Commission guidance and scrutiny. If the old maxim is applied, then the Commission should assume the responsibility for the added portion of debt that was generated under its mission.

\section{Bibliographic references}

ASH, Timothy G. (2012) The Crisis of Europe. Foreign Affairs, Vol. 91, n. 5, p. 2-15.

BLYTH, Mark (2013) Austerity. The History of a Dangerous Idea. Oxford: OUP.

CINI, Michelle (2002) Reforming the European Commission: discourse, culture and planned change. In Hosli, M. O. et al. (Eds.) Institutional Challenges in the European Union. London: Routledge, p. 1-21.

EUROPEAN COMMISSION (2013) General Government Data. General Government Revenue, Expenditure, Balances and Gross Debt. Part I. Autumn 2013.

EUROPEAN PARLIAMENT (2014) The Troika and financial assistance in the euro area: successes and failures. PE 497.764. February 2014.

FELDSTEIN, Martin (2012) The Failure of the Euro. Foreign Affairs, Vol. 91, n. 1, p. 105-116. KRUGMAN, Paul (2012) End This Depression Now!. New York: W. W. Norton \& Company. MORAVCSIK, Andrew (2012) Europe After the Crisis. Foreign Affairs, Vol. 91, n. 3, p. 54-68. PETERSON, John (2006) The College of Commissioners. In Peterson, J. and Shackleton, M. (Eds.) The Institutions of the European Union, $2^{\text {nd }}$ ed. Oxford: OUP, p. 81-103.

PIKETTY, Thomas (2013) Le Capital au XXI ${ }^{\mathrm{ème}}$ Siècle. Paris: Éditions du Seuil. 
PIRIS, Jean-Claude (2012) The Future of Europe. Towards a Two-Speed EU. Cambridge: CUP. PISANI-FERRY, Jean et al. (2013) EU-IMF assistance to euro-area countries: an early assessment. Bruegel Blueprint Series, Vol. XIX.

REINHART, Carmen and ROGOFF, Kenneth (2010) Growth in a Time of Debt. American Economic Review, Vol. 100, n. 2, p. 573-78.

STREECK, Wolfgang (2013) Gekaufte Zeit. Die vertagte Krise des demokratischen Kapitalismus. Berlin: Suhrkamp Verlag, [Versão portuguesa (2013): Tempo Comprado. A crise adiada do capitalismo democrático. Lisboa: Actual].

WEBBER, Douglas (2013) How likely is that the European Union will disintegrate? A critical analysis of competing theoretical perspectives. European Journal of International Relations, Vol. 19, p. 1-25.

ZAPATERO, José Luis Rodríguez (2013) El Dilema. 600 días de vértigo. Barcelona: Editorial Planeta.

\author{
Submitted on February 9, 2015 \\ Accepted on March 13, 2015
}

\begin{abstract}
The article is intended to debate two questions regarding the involvement of the Commission in the Troika's action: firstly, considering the nature of financial assistance programs, it aims to discuss the effect of the Commission's participation in Troika negotiations on the balance of power of the EU institutions; and secondly, the article raises the issue of the Commission's liability for the results achieved by the financial assistance program, taking into account the extent of the conditions imposed, as well as the intensity of scrutiny by the Troika.
\end{abstract}

Keywords: European Union; European Commission; Troika.

\title{
Resumo
}

Este artigo pretende debater duas questões relativas à participação da Comissão Europeia na chamada Troika: primeiro, e considerando a natureza dos programas de assistência financeira, questiona os efeitos da participação da Comissão na Troika sobre o equilíbrio de poderes existente entre as instituições europeias; em segundo lugar, o artigo levanta o problema da responsabilidade da Comissão pelos resultados alcançados pelos programas de assistência financeira, tendo em conta não apenas o condicionalismo imposto, mas também a intensidade do escrutínio realizado pela Troika.

Palavras-chave: União Europeia; Comissão Europeia; Troika. 